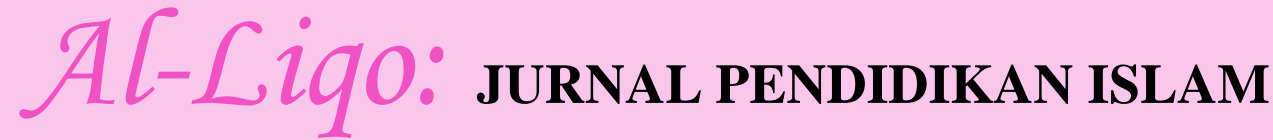 \\ P-ISSN: 2461-033X | E-ISSN: 2715-4556
}

\section{Tradisi Semaan Al-Quran di Pondok Pesantren}

\author{
Maskur Maskur ${ }^{1)}$ \\ Email: maskur2106128401@gmail.com ${ }^{1}$
}

${ }^{1)}$ Sekolah Tinggi Agama Islam Walisembilan Semarang (SETIAWS), Jawa Tengah, Indonesia

\begin{abstract}
One of the efforts to study the contents of the Qur'an is Semaan tradition. This study used a qualitative approach, the subjects were Kyai, the teachers, the administrators, and the students of the Ibrohimiyyah Mranggen Islamic boarding school. The school has a lot of students ranging in age 6 to 12 years. Primary data sources were obtained directly from the field through observation and interviews, while the secondary sources were obtained from the documents. The results showed that the Semaan activities were carried out under planning, implementation, and evaluation. That was always conducted in teaching the Al-Quran to students.
\end{abstract}

Keywords: Semaan, Tradition, Al-Quran

\section{Abstrak}

Salah satu upaya yang dilakukan untuk mempelajari isi Al-Quran adalah dengan tradisi semaan AlQuran. Pendekatan penelitian yang digunakan pada penelitian ini adalah pendekatan kualitatif, subjek penelitian adalah Kyai, para pengasuh, pengelola pondok dan para santri pondok pesantren Ibrohimiyyah Mranggen yang merupakan salah satu pondok pesantren yang memiliki banyak santri berusia rentang $6-12$ tahun. Sumber data primer diperoleh secara langsung dari lapangan melalui observasi dan wawancara. Sumber data sekunder diperoleh dari dokumen-dokumen yang diperlukan dalam penelitian. Teknik dokumentasi digunakan untuk mengumpulkan data sekunder dari berbagai dokumen. Hasil penelitian menunjukkan kegiatan semaan Al-Quran dilaksanakan sesuai dengan perencanaan, pelaksanaan dan evaluasi senantiasa dilakukan untuk mengajarkan Al-Quran kepada para santri.

Kata Kunci: Semaan, Tradisi, Al-Quran

Cara Mensitasi Artikel:

Maskur, M. (2021). Tradisi semaan Al-Quran di Pondok Pesantren. Al-Liqo: Jurnal Pendidikan Islam, 6(1), 68-82. https://doi.org/10.46963/alliqo.v6i1.320.

\begin{tabular}{|l|l|l|}
\hline \multicolumn{1}{|c|}{$\begin{array}{l}\text { *Corresponding Author: } \\
\text { maskur2106128401@gmail.com }\end{array}$} & \multicolumn{1}{c|}{ Histori Artikel: } \\
\hline $\begin{array}{l}\text { Editorial Address: Kampus Parit Enam, STAI } \\
\text { Auliaurrasyidin Tembilahan. Jl. Gerilya No. 12 } \\
\text { Tembilahan Barat, Riau Indonesia 29213. }\end{array}$ & Diterima & $: 27 / 03 / 2021$ \\
& Direvisi & $:-$ \\
\hline
\end{tabular}

DOI: https://doi.org/10.46963/alliqo.v6i1.320

\section{PENDAHULUAN}

Al-Quran merupakan firman Allah SWT yang menjadi pedoman hidup manusia. Al-Quran memiliki peranan penting bagi kehidupan manusia, salah satunya sebagai fondasi dasar pengetahuan keberagamaan umat Islam. Substansi Islam bersumber pada Al-Quran yang sekaligus dapat dijadikan sebagai falsafah hidup bagi mereka yang mengimaninya. Pernyataan ini sesuai dengan pernyataan 
Tradisi Semaan Al-Quran di Pondok Pesantren

Safwat M. Halilovic, yang menjelaskan bahwa "The Qur'an is the principal source of Islam and the essence of Islamic living in an ideological, legal and moral respect. That is why the Qur'an is the core of Islamic way of life. The life of a Muslim is focused on the Qur'an, which is present in all of its phases (Safwat M. Halilovic, 2005: 25).

Berdasarkan pernyataan tersebut dapat diketahui bahwa umat muslim dituntut untuk bisa memanifestasikan inti ajaran Islam melalui Al-Quran dalam tiap-tiap aspek kehidupannya. Dengan demikian perlu upaya untuk selalu melestarikan nilainilai yang terkandung dalam Al-Quran dengan melakukan berbagai cara yakni membiasakan membaca maupun memahami isi Al-Quran. Salah satu upaya yang dilakukan untuk mempelajari isi Al-Quran adalah dengan adanya tradisi semaan Al-Quran. Semaan adalah Tradisi membaca dan mendengarkan pembacaan AlQuran. Kata 'semaan' berasal dari bahasa Arab sami'a-yasma'u, yang artinya mendengar. Kata tersebut diserap ke dalam bahasa Indonesia menjadi "simaan" atau "simak", dan dalam bahasa Jawa disebut "semaan". Dalam penggunaannya, kata ini tidak diterapkan secara umum sesuai asal maknanya, tetapi digunakan secara khusus kepada suatu aktivitas tertentu para santri atau masyarakat umum yang membaca dan mendengarkan lantunan ayat suci Al-Quran.

Tradisi semaan Al-Quran adalah tradisi yang dilakukan dengan membaca dan mendengarkan Al-Quran berjamaah atau bersama-sama, di mana dalam semaan tersebut, ada yang membaca dan ada pula yang mendengarkan lantunan ayat AlQuran.

Tradisi merupakan keseluruhan benda material dan gagasan yang berasal dari masa lalu namun masih benar-benar ada hingga kini, belum dihancurkan, dirusak, dibuang atau dilupakan. Tradisi adalah nilai dan norma yang diyakini dari satu generasi ke generasi yang lainnya, Nanang Martono (2012: 315). Tradisi pada dasarnya terlahir dan dipengaruhi oleh masyarakat, kemudian masyarakat muncul dan dipengaruhi tradisi. Tradisi pada mulanya merupakan musabab, namun pada akhirnya menjadi konklusi dan premis, isi dan bentuk, efek dan aksi pengaruh dan mempengaruhi, Hasan Hanafi (2003: 2). 
Berdasarkan definisi tradisi tersebut, dapat diketahui bahwa tradisi merupakan keseluruhan warisan baik yang bersifat material kebendaan maupun segala gagasan dari generasi yang dulu hingga pada generasi sekarang dan masih terjaga hingga sekarang. Tradisi sebagai sebuah warisan mengandung arti bahwa tradisi tersebut merupakan bagian dari apa yang dimiliki oleh nenek moyang kepada generasi yang sekarang. Makna warisan jelas berarti bahwa tradisi harus dijaga dengan baik, agar warisan yang ditinggalkan akan tetap terjaga dengan baik.

Tradisi semaan Al-Quran biasanya merupakan salah satu tradisi yang perlu dilestarikan, karena memiliki manfaat yang besar dalam menanamkan nilai-nilai ajaran Islam yang terkandung dalam Al-Quran itu sendiri. Tradisi ini umumnya dilakukan oleh masyarakat pada saat bulan Ramadhan tiba untuk mengisi waktu luang atau sembari menunggu datangnya waktu buka puasa, akan tetapi di luar waktu Ramadhan, umunya tradisi ini tidak dilakukan kembali. Tradisi ini tentunya juga perlu dipupuk dan dilaksanakan di luar bulan Ramadhan karena akan memberikan manfaat yang luar biasa bagi masyarakat yang melakukan tradisi ini. Tradisi semaan Al-Quran yang dilakukan masyarakat umum biasanya dilakukan di masjid yang dilakukan secara bersama-sama oleh masyarakat sekitar masjid. Tradisi semaan Al-Quran tersebut sayangnya hanya dilakukan pada saat bulan Ramadhan saja.

Berbeda dengan tradisi semaan Al-Quran di pondok pesantren, tradisi ini biasanya rutin dilakukan oleh para santri. Tradisi semaan Al-Quran umunya dilakukan di pondok pesantren sebagai salah satu metode untuk menghafalkan AlQuran. Tradisi ini salah satunya dapat dilihat di pondok pesantren Ibrohimiyyah Mranggen Demak. Semaan Al Quran di pondok pesantren tersebut dilakukan sebagai suatu metode untuk menghafalkan Al-Quran, di mana setiap santri secara bergantian membaca dan mendengarkan Al-Quran secara berulang-ulang hingga santri bisa menghafal Al-Quran yang didengarkan atau dibacanya.

Tradisi tersebut tentunya dapat dijadikan sebagai salah satu indikasi semangat belajar seorang santri untuk mempelajari Al-Quran. Dengan melihat tingkat kerajinan seorang santri untuk membaca atau mendengarkan Al-Quran melalui tradisi semaan, maka secara langsung atau tidak langsung dapat dilihat semangat 
Tradisi Semaan Al-Quran di Pondok Pesantren

seorang santri untuk mempelajari Al-Quran. Seorang santri yang memiliki intensitas yang tinggi melakukan semaan Al-Quran tentunya dapat dijadikan sebagai salah satu indikator semangat santri untuk mempelajari Al-Quran. Berdasarkan latar belakang tersebut, penulis ingin meneliti tentang tradisi semaan Al-Quran terhadap semangat santri untuk mempelajari Al-Quran di pondok Pesantren.

\section{METODE}

Pendekatan penelitian yang digunakan adalah pendekatan kualitatif, data berasal dari wawancara, dan observasi, sehingga yang menjadi tujuan dari penelitian ini adalah ingin menggambarkan Realita Empirik dibalik fenomena yang terjadi secara mendalam dan rinci. Oleh karena itu, penggunaan pendekatan kualitatif dalam penelitian ini adalah dengan mencocokkan antara Realita Empirik dengan teori yang berlaku dengan menggunakan metode deskriptif. Sumber data terbagi:

1. Sumber Data Primer

Sumber data primer diperoleh secara langsung dari lapangan melalui observasi dan wawancara dengan informan. Observasi dilakukan dengan mengamati kegiatan di pondok pesantren Ibrohimiyyah dengan melihat penyelenggaraan pendidikan secara menyeluruh, sedangkan wawancara untuk menggali data dari pengelola pondok, pengasuh maupun para santri.

2. Sumber Data Sekunder

Sumber data sekunder diperoleh dari dokumen-dokumen yang diperlukan dalam penelitian ini terutama berkaitan dengan penyelenggara pendidikan di pondok pesantren Ibrohimiyyah Maranggen.

\section{HASIL DAN PEMBAHASAN}

Berdasarkan kajian pustaka tersebut di atas, penelitian yang akan peneliti teliti berbeda dengan penelitian-penelitian sebelumnya. Hal ini karena penelitian yang akan peneliti lakukan berkaitan dengan implementasi tradisi semaan Al-Quran di Pondok pesantren Ibrohimiyyah. Sedangkan landasan teori terdapat beberapa teori diantaranya: 


\section{Memahami Semaan Al-Quran}

Semaan Al-Quran sebagai salah satu metode dalam menghafal Al-Quran merupakan metode yang telah dipakai sejak lama dalam mempelajari Al-Quran. Memahami bahwa menghafal Al-Quran merupakan salah satu hal yang tidak mudah, maka hal yang terpenting tentunya adalah memahami bahwa menghafal AlQuran merupakan bentuk keimanan manusia kepada Allah SWT.

Semaan menurut kamus Bahasa Arab dari kata Sami'a yang berarti mendengarkan atau menyimak, sedangkan semaan Al-Quran yaitu kegiatan muslim mendengarkan, menyimak lantunan ayat-ayat suci Al-Quran yang dilantunkan oleh Hufą̧u Al-Quran (penghafal Al-Quran) sebagai sarana taqorrub (mendekatkan diri) kepada Allah untuk jalan menuju Taubat sekaligus menjadi sarana introspeksi diri, mengadu, silaturahmi antar sesama umat Islam dan doa bersama sekaligus sebagai sarana ungkapan cinta kita kepada Allah, Rasulullah, Sahabat, Auliya', Salafushsholih, Ulama, Orang tua dan segenap saudara muslim (yang masih hidup atau yang sudah meninggal).

Kamus Bahasa Indonesia menjelaskan kata semaan yaitu "simaan" atau "simak", dan dalam Bahasa Jawa disebut"semaan". Dalam penggunaannya, kata ini tidak diterapkan secara umum sesuai asal maknanya, tetapi digunakan secara khusus kepada suatu aktivitas tertentu para santri atau masyarakat umum yang membaca dan mendengarkan lantunan ayat suci Al-Quran. Tidak hanya sekadar membaca dan mendengar Al-Quran, penggunaan kata semaan saat ini secara ketat disematkan kepada sejumlah orang yang membaca dan menghafal Al-Quran dengan cara menghafalnya.

Semaan pada dasarnya dapat dijadikan semaan dapat dijadikan sebagai metode menghafal Al-Quran yaitu biasanya berkumpul minimal dua orang, atau bisa juga lebih, yang salah satu di antara mereka ada yang membaca Al-Quran (tanpa melihat teks ayat), sementara yang lainnya mendengar serta menyimaknya. Pendengar sangat bermanfaat dalam metode hafalan ini, sebab mereka bisa melakukan koreksi atau membenarkan jika pelantun Al-Quran itu membacanya salah. Ada pula pengertian bahwa semaan adalah kegiatan membaca dan mendengarkan Al-Quran berjamaah atau bersama-sama, di mana dalam semaan itu 
Tradisi Semaan Al-Quran di Pondok Pesantren

juga selain mendengarkan Al-Quran, yang hadir (sami'in) juga bersama-sama melakukan ibadah Shalat wajib secara berjamaah juga shalat-shalat sunah yang lain, dari ba'da subuh hingga khatamnya Al-Quran.

Memahami bahwa hakikat menghafal Al-Quran sebagai bentuk keimanan manusia, maka hal yang betul-betul didasari keimanan dalam hati, dengan cara berpikir berikut ini:

1. Keinginan atau kesadaran menghafal Al-Quran sesungguhnya hasil dari tilawah yang dilakukan secara intensif. Apabila dalam sehari tilawah sejuz sampai lima juz dalam waktu setahun-dua tahun, niscaya akan menghasilkan iman yang hidup. Iman yang akan menjadikannya merasakan bahwa menghafal Al-Quran adalah kegiatan yang menyenangkan, meskipun banyak kendala yang harus dilalui.

2. Iman yang semakin baik, maka akan menjadikan seseorang menghafal AlQuran bukanlah semata-mata mengcopypaste ayat-ayat Al-Quran ke dalam pikiran, namun suatu kegiatan untuk berlama-lama berinteraksi dengan AlQuran.

3. Menghafal merupakan upaya orang yang beriman untuk mempersiapkan kehidupan di akhirat, untuk mendapatkan syafaat Al-Quran, sehingga lebih memudahkan mereka untuk masuk surga dan selamat dari api neraka. Barang siapa yang dalam dirinya belum memiliki iman yang bulat terhadap kehidupan akhirat, maka ia tidak akan maksimal dalam menikmati Al-Quran.

4. Menghafal Al-Quran adalah upaya untuk membekali diri, mencapai spiritualitas yang sehat agar kuat dan teguh dalam menjalani setiap kehidupan yang dipenuhi dengan ujian. Barang siapa yang bertakwa, Allah akan memberikan keteguhan dalam menghadapi ujian kehidupan dan memberi jalan keluar dari berbagai macam kesulitan dalam kehidupan.

5. Menghafal Al-Quran merupakan upaya untuk membekali diri dengan ilmu-ilmu yang sangat berharga. Apabila kita merenungi isi Al-Quran, sesungguhnya penuh dengan ilmu yang bermanfaat, apalagi bila hafal satu juz, terlebih 30 juz dan terus mentadaburinya. 
Dalam mempelajari Al-Quran, hal yang perlu ditanamkan kepada seluruh santri adalah memperbaiki perilakunya yaitu:

1. Harus meyakini bahwa pada prinsipnya, setiap mukmin dituntut untuk terus membaca dan menghafalkan Al-Quran. Keduanya memiliki peran yang sangat besar dalam pembinaan umat.

2. Secara bertahap, tentukan target yang akan dicapai dalam tilawah. Begitu pula target tahfidz yang ingin dicapai. Sangat dianjurkan menentukan target agar dalam pelaksanaannya tidak terbebani perasaan yang membuat ragu dan akhirnya berhenti sebelum memulai. Dalam menghafal Al-Quran tentunya harus dilakukan secara bertahap, sedikit demi sedikit sesuai dengan kemampuan santri. Hal tersebut tentunya akan mempermudah santri dalam menghafal AlQuran.

3. Tentukan jangka waktu yang kita inginkan. Usahakan disiplin dengan ketentuan yang telah kita buat niscaya Allah akan memberikan kemudahan dan kenikmatan Al-Quran yang sangat besar. Disiplin merupakan salah satu kunci keberhasilan santri dalam belajar, sehingga harus menanamkan disiplin kepada para santri sehingga akan mempermudah target dalam menghafal Al-Quran.

4. Lakukan upaya mengganti setiap kali kita menyalahi waktu yang telah kita tetapkan sebelumnya. Dalam mempelajari Al-Quran harus senantiasa memiliki kontrol diri yang baik, sehingga bila apa yang telah dilakukan tidak sesuai target, maka harus segera diperbaiki.

\section{Keutamaan Semaan Al-Quran}

Semaan Al-Quran dapat dipahami bahwa menyimak dapat dikatakan terdapat aktifitas membaca atau mendengarkan Al-Quran. Kegiatan membaca maupun mendengarkan Al-Quran pada dasarnya sama-sama pentingnya dalam mempelajari Al-Quran. Adapun keutamaan membaca maupun mendengarkan Al-Quran dapat dijelaskan sebagai berikut:

1. Keutamaan membaca Al-Quran

Membaca Al-Quran merupakan pekerjaan yang utama, yang mempunyai berbagai keistimewaan dan kelebihan dibandingkan dengan membaca bacaan yang lain. Adapun keutamaan membaca Al-Quran diantaranya sebagai berikut: 
Tradisi Semaan Al-Quran di Pondok Pesantren

a. Menjadi manusia yang terbaik.

b. Orang yang mahir membaca Al-Quran tingkatannya bersama para malaikat

c. Al-Quran sebagai hidangan Allah SWT

d. Rumah dibacakan Al-Quran dihadiri para malaikat dan menjadi leluasa bagi penghuninya

e. Rumah yang dibacakan Al-Quran terpancar sinar hingga ke penduduk langit

f. Membaca Al-Quran akan menjadikan begitu banyak kebaikan dan keberkahan

g. Membaca Al-Quran akan memperindah pembacanya

h. Membaca Al-Quran adalah penerang bagi hati

i. Membaca Al-Quran sangat bermanfaat bagi pembaca dan orang tuanya

j. Pembaca Al-Quran tidak akan terkena bencana di hari kiamat kelak

k. Al-Quran memberi syafaat kepada pembacanya

I. Bacaan Al-Quran mengharumkan pendengarnya dengan minyak dan misik (minyak kasturi).

2. Keutamaan mendengarkan Al-Quran

Bukan membaca Al-Quran saja yang menjadi ibadah dan amal yang mendapat pahala dan rahmat, tetapi mendengarkan bacaan Al-Quran pun begitu pula. Sebagian ulama mengatakan, bahwa mendengarkan orang membaca AlQuran pahalanya sama dengan orang yang membacanya. Adapun keutamaan membaca Al-Quran di antaranya sebagai berikut:

a. Sebab mendapat rahmat Allah SWT.

b. Sebab seseorang meraih hidayah.

c. Sebab kekhusu'an hati dan mencucurkan air mata.

d. Sebab bertambahnya iman.

e. Al-Quran memberi syafa'at kepada pendengarnya

Perlu disadari bahwa selain metode yang baik, beberapa faktor dalam mempelajari Al-Quran sangatlah banyak, diantaranya:

1. Keluarga

Keluarga merupakan poros dan arah penentu pendidikan itu sendiri. Anak yang tumbuh dilingkungan yang mencintai Al-Quran, gemar menghafal dan 
mempelajarinya, maka anak akan tumbuh sesuai dengan yang dilihat dilingkungannya

2. Peran ayah

Tidak ringan halangan yang dihadapi seorang kepala keluarga dalam menuntun anggota keluarganya menuju jalan surga. Oleh sebab itu, seorang ayah harus memiliki stok kesabaran yang lebih. Dan senantiasa memohon pertolongan dari Allah

3. Peran Ibu

Ibu adalah madrasah pertama bagi anak-anaknya. Selain itu, ibu juga memiliki peran penting dalam pendidikan keluarga. Untuk mendidik anak agar menjadi seorang Hafidz Al-Quran, maka seorang ibu harus cekatan, telaten, dalam berbagai hal.

4. Lingkungan

Allah menyatakan dalam Al-Quran, bahwasanya salah satu sebab utama yang membantu para sahabat Nabi untuk tetap semangat dalam iman dan mempelajari Al-Quran adalah keberadaan Rasulullah di tengah-tengah mereka. Begitu juga dengan orang-orang yang sudah memutuskan untuk menghafal AlQuran, maka harus menata lingkungan agar mendukung berlangsungnya proses menghafal.

\section{Implementasi Tradisi Semaan Al-Quran}

Tradisi Semaan Al-Quran di pondok pesantren telah menjadi bagian proses pembelajaran Al-Quran yang dilakukan di pondok pesantren. Sebagai salah satu pondok pesantren yang menekankan hafalan Al-Quran dalam proses pembelajarannya, sehingga semaan Al-Quran menjadi salah satu metode yang digunakan untuk mengajarkan Al-Quran bagi para santri. Semaan Al-Quran dilakukan secara terprogram sebagai bagian proses pembelajaran dan harus dilaksanakan oleh para santri. Adapun kegiatan semaan Al-Quran dilaksanakan secara terjadwal mulai dari setelah Shalat subuh, setelah Shalat Ashar dan setelah Shalat magrib.

Santri memang tidak ditarget untuk dapat menghafalkan Al-Quran, tetapi lebih melihat potensi dari setiap santri. Semaan Al-Quran biasanya dibimbing dan 
Tradisi Semaan Al-Quran di Pondok Pesantren

diarahkan oleh para pengasuh dan pengajar di pondok pesantren di waktu seusai Shalat subuh dan Shalat ashar. Adapun setelah Shalat magrib para santri akan setoran hafalan ke pengajar Al-Quran. Kegiatan semaan selain menjadi tradisi setiap hari, juga dilakukan bila ada event-event tertentu yang menjadi kegiatan rutin pondok pesantren, misalnya kegiatan khoul pendiri pondok pesantren dan kegiatan khotmil Quran serta kegiatan pengajian rutin yang dilakukan setiap bulan sekali.

Semaan Al-Quran biasanya dilaksanakan secara berkelompok dan juga secara individu yang diarahkan oleh para pengajar. Kegiatan semaan Al-Quran tentunya dilaksanakan sesuai dengan perencanaan, pelaksanaan dan evaluasi yang senantiasa dilakukan untuk mengajarkan Al-Quran kepada para santri. Kegiatan perencanaan dilakukan dengan melihat tingkatan masing-masing santri dalam mempelajari AlQuran dan merencanakan metode maupun pelaksanaan dalam mengimplementasikan tradisi semaan Al-Quran. Pelaksanaan semaan Al-Quran lebih diutamakan dalam menghafal Al-Quran secara berkelompok maupun secara individu. Pembelajaran secara berkelompok biasanya dilakukan untuk mempermudah dan memberi motivasi santri untuk belajar Al-Quran. Kegiatan pembelajaran dilakukan dengan membagi kelompok dengan jumlah santri per kelompok yaitu 6 orang. Dengan membagi ke dalam sebuah kelompok, santri yang belum menguasai dalam membaca maupun menghafal akan termotivasi dengan melihat santri yang sudah mampu membaca dan menghafal dengan baik. Di samping itu, bagi santri yang sudah pandai dapat menyimak pada saat santri lain membaca Al-Quran dan mengajari bagi santri yang belum bisa.

Pembelajaran secara individu dilakukan untuk memperdalam bacaan dan menambah hafalan santri. Pembelajaran secara individu tetap didampingi pengajar agar bacaan santri tetap terkontrol dengan baik. Selain semaan secara berkelompok dan secara individu, santri juga diberi kesempatan untuk selalu setor hafalan setiap harinya. Banyak atau sedikitnya hafalan ditentukan dari kemampuan santri dalam menghafal setiap harinya, sehingga tidak ditentukan dari usia santri. Usia yang muda bisa saja lebih unggul dalam menghafal sehingga telah mampu menghafal lebih banyak juz daripada santri yang lebih dewasa. 
Semaan Al-Quran dalam proses penilaiannya dilakukan setiap proses pembelajaran. Adapun unsur penilaian dalam proses pembelajaran adalah tajwid, kelancaran dan kefasihan dalam membaca Al-Quran. Dengan demikian penilaian dilakukan secara langsung pada saat semaan Al-Quran dilaksanakan. Semaan AlQuran sebagai salah satu metode dalam mempelajari Al-Quran merupakan salah satu metode yang cukup banyak dipilih oleh beberapa pondok pesantren, adapun metode yang dapat dijadikan perbandingan dalam mempelajari Al-Quran yaitu dengan:

1. Mengikatnya dengan kepribadian Nabi sebagai teladan, Apabila peserta didik telah diikat dengan keteladanan Nabi, maka dapat menjadikannya manusia Shaleh, bertakwa, lurus, dan mencintai Al-Quran dan ilmu. Maka tak diragukan lagi meneladani Nabi merupakan motivasi yang paling kuat, hebat, bermanfaat, dan paling banyak meresap dan menetap dalam jiwa.

2. Memberikan pujian, Pujian memiliki dampak positif di dalam jiwa. Pujian pada waktu yang tepat, kesempatan yang tepat, serta untuk orang yang tepat pula, dapat membangkitkan semangat dan meningkatkan kekuatan di dalam jiwa. Sehingga, seseorang yang tengah berjuang menghafal Al-Quran meskipun banyak kekurangan akan tetap semangat dengan adanya pujian tersebut.

3. Kompetisi, Kompetisi dapat menggerakkan energi yang tersembunyi di dalam diri seseorang. Inilah sarana penting yang menegaskan urgensi menanamkan jiwa kompetisi diantara peserta didik. Setelah itu, memberikan hadiah kepada pemenangnya, sehingga menghafal Al-Quran terasa menyenangkan.

4. Memecahkan persoalan, Kadang kala santri yang rajin mengalami masa-masa malas dan enggan. Maka, hal pertama yang dilakukan seorang guru dalam hal ini ialah mengetahui fase-fase yang dialami peserta didik. Apabila seorang pengajar telah mengetahui tabiat dan rahasia dari setiap fase tersebut, maka guru akan menerapkannya pada akal dan hati para santri

5. Merespons kecenderungan dan memenuhi keinginan, Satu hal yang bermanfaat adalah memberi motivasi, rangsangan dan penghargaan baginya dengan merespons kecenderungannya. 
Tradisi Semaan Al-Quran di Pondok Pesantren

6. Menaruh kepercayaan, Ketika pendidik memandang peserta didiknya dengan pandangan penuh kepercayaan bahwa ia akan sanggup menghafal Al-Quran, maka peserta didik akan merasakan bahwa dirinya sanggup menghafal AlQuran. Dan akan muncul pada dirinya keinginan di dalam dirinya untuk mewujudkannya.

7. Menumbuhkan kepercayaan diri murid. Peserta didik yang memiliki kepercayaan diri lebih, dia akan merasa apa yang diusahakan akan berhasil. Berbeda dengan peserta didik yang tidak memiliki percaya diri, ia tidak akan mau bersungguh-sungguh dalam berusaha karena ia mengira menghafal AlQuran tidak akan ada hasilnya.

\section{Dampak Tradisi Semaan Al-Quran}

Semaan Al-Quran yang dilakukan di pondok pesantren Ibrohimiyyah adalah kegiatan menyimak bacaan Al-Quran oleh para santri dengan tujuan agar santri mengerti bagaimana mengaji Al-Quran dengan tartil dan fasih. Dianggap tepat untuk mengajarkan Al-Quran kepada santri anak-anak yang masih di usia dini maupun usia sekolah dasar. Metode ini telah diyakini pondok pesantren Ibrohimiyyh sebagai metode yang cukup tepat untuk mengajarkan santri-santri penghafal Al-Quran. Mengingat kegiatan semaan Al-Quran dilakukan tidak hanya untuk mengajarkan kepada santri pondok pesantren, tetapi juga dilakukan untuk mengajarkan Al-Quran kepada masyarakat melalui berbagai event-event tertentu secara jelas akan memberikan dampak bagi semua pihak yang terlibat terutama bagi santri maupun masyarakat sekitar. Metode semaan Al-Quran sebagai salah satu metode pembelajaran dalam menghafal Al-Quran yang memang sudah bertahuntahun dan turun temurun dilakukan di pondok pesantren. Hasil dari metode semaan juga telah banyak mengantarkan santri untuk hafal Al-Quran 30 Juz.

Berdasarkan hasil penelitian dapat diketahui bahwa dampak semaan AlQuran dapat dirasakan oleh santri maupun pengajar dan pengelola pondok pesantren. Adapun dampak tersebut adalah sebagai berikut: 
1. Santri dapat memperoleh manfaat spiritual yang luar biasa dengan menghafal Al-Quran.

Menghafalkan Al-Quran memiliki manfaat-manfaat yang berkaitan erat dengan ruh dan jiwa. Menghafal Al-Quran juga mendatangkan manfaat diantaranya adalah: Pertama, para penghafal Al-Quran merupakan aktor-aktor Rabbani. Kedua, para penghafal Al-Quran merupakan "keluarga" Allah dan orang kepercayaan-Nya. Ketiga, para penghafal Al-Quran disejajarkan kemuliaannya dengan para malaikat. Keempat, para penghafal Al-Quran mendapatkan tempat tertinggi di akhirat. Kelima, para penghafal Al-Quran mendapatkan jaminan surga dan memberi syafaat untuk sepuluh orang anggota keluarga. Keenam, para penghafal Al-Quran akan diridai Allah dan dianugerahi mahkota kehormatan di dalam surga. Ketujuh, dalam pengadilan di akhirat para penghafal Al- Quran akan dibela oleh surat-surat Al-Quran yang mereka hafalkan. Kedelapan, para penghafal Al-Quran adalah orang-orang yang jiwanya tenteram dan bahagia. Para santri umumnya senang dan merasa bahagia dapat menghafalkan Al-Quran, sehingga para santri memiliki motivasi yang besar untuk selalu mempelajari Al-Quran.

2. Santri memperoleh manfaat fisik dan motivasi hidup lebih baik.

Berdasarkan hasil penelitian dapat diketahui bahwa santri dapat memperoleh manfaat fisik dan motivasi untuk hidup dengan lebih baik. Manfaat fisik yang dirasakan oleh para santri adalah semakin berkembangnya kemampuan berpikir, dan menjadi pribadi yang sehat, mandiri dan bermanfaat bagi orang tua dan masyarakat sekitar. Dengan menghafal Al-Quran menjadikan santri menjadi lebih santun dan berperilaku yang baik sehingga membuat santri menjadi termotivasi untuk hidup lebih baik. Santri merasakan beberapa manfaat tersebut sebagai bagian terpenting dalam menghafal AlQuran, sehingga akan menambah motivasi santri dalam menghafal Al-Quran dan mengamalkannya dalam kehidupannya sehari-hari.

3. Metode semaan Al-Quran menjadikan lebih mudah menghafal Al-Quran.

Dengan menggunakan metode semaan Al-Quran banyak santri yang terbantu dalam menghafal secara lebih mudah. Hal tersebut karena metode 
Tradisi Semaan Al-Quran di Pondok Pesantren

dilakukan secara individu maupun kelompok yang dapat memudahkan santri yang belum bisa menghafal. Santri yang telah pandai membaca dengan fasih akan membantu santri yang belum bisa, sehingga santri yang belum bisa akan berusaha untuk mampu menghafal dengan baik.

4. Santri dan masyarakat sekitar menjadi lebih bersemangat dalam memperdalam ilmu agama.

Dengan adanya beberapa event seperti semaan rutin yang dilakukan untuk santri maupun masyarakat sekitar menjadikan santri dan masyarakat menjadi bersemangat dalam belajar ilmu agama terutama dalam menghafal Al-Quran. Semangat dalam memperdalam ilmu agama tentunya dengan melihat antusias santri maupun masyarakat yang secara rutin dan konsisten dalam belajar, sehingga mampu memberikan semangat bagi para santri maupun masyarakat yang senantiasa ingin selalu belajar.

\section{KESIMPULAN}

Berdasarkan hasil penelitian yang dilakukan, dapat disimpulkan bahwa kegiatan semaan Al-Quran dilaksanakan sesuai dengan perencanaan, pelaksanaan dan evaluasi yang senantiasa dilakukan untuk mengajarkan Al-Quran kepada para santri. Kegiatan perencanaan dilakukan dengan melihat tingkatan masing-masing santri dalam mempelajari Al-Quran dan merencanakan metode maupun pelaksanaan dalam mengimplementasikan tradisi semaan Al-Quran. Pelaksanaan semaan Al-Quran lebih diutamakan dalam menghafal Al-Quran secara berkelompok maupun secara individu. Pembelajaran secara individu dilakukan untuk memperdalam bacaan dan menambah hafalan santri. Pembelajaran secara individu tetap didampingi pengajar agar bacaan santri tetap terkontrol dengan baik. Selain semaan secara berkelompok dan secara individu, santri juga diberi kesempatan untuk selalu setor hafalan setiap harinya. Banyak atau sedikitnya hafalan ditentukan dari kemampuan santri dalam menghafal setiap harinya, sehingga tidak ditentukan dari usia santri. Usia yang muda bisa saja lebih unggul dalam menghafal sehingga telah mampu menghafal lebih banyak juz daripada santri yang lebih dewasa. Semaan Al-Quran dalam proses penilaiannya dilakukan setiap proses pembelajaran. Adapun unsur penilaian dalam proses pembelajaran adalah 
tajwid, kelancaran dan kefasihan dalam membaca Al-Quran. Adapun penilaian dilakukan secara langsung pada saat semaan Al-Quran dilaksanakan

Sedangkan dampak dari tradisi semaan Al-Quran adalah yaitu, Santri dapat memperoleh manfaat spiritual yang luar biasa dengan menghafal Al-Quran, Santri memperoleh manfaat fisik dan motivasi hidup lebih baik, Metode semaan Al-Quran menjadikan lebih mudah menghafal Al-Quran, Santri dan masyarakat sekitar menjadi lebih bersemangat dalam memperdalam ilmu agama.

Berdasarkan hasil penelitian, saran yang dapat direkomendasikan terutama untuk tempat penelitian ini yaitu Menambah sarana dan prasarana dalam mendukung tradisi semaan Al-Quran di pondok pesantren, Menambah jumlah pengajar yang mampu mengajar Al-Quran salah satunya dengan menggunakan metode semaan Al-Quran. Menambah event-event rutin dalam melaksanakan tradisi semaan Al-Quran.

\section{REFERENSI}

Arikunto, S. (2006). Metodologi penelitian. Yogyakarta: Bina Aksara.

Arikunto, S. (2006). Prosedur Penelitian Suatu Pendekatan Praktek. Jakarta: PT Rineka Cipta

Danim, S. (2002). Menjadi Peneliti Kualitatif. Bandung: Pustaka Setia

Hasan, H. (2003). Oposisi Pasca Tradisi. Yogyakarta: Sarikat

Moleong, L. J. (2007). Metodologi Penelitian Kualitatif. Bandung: PT Remaja Rosdakarya

Nanang, M. (2012). Sosiologi Perubahan Sosial: Perspektif Klasik, Modern, Postmodern, dan Poskolonial. Jakarta: PT. Rajagrafindo Persada

Safwat, M. H. (2005). Hifz-Memorization of The Qur'an. Cairo: Dar al-Salam

Sugiyono. (2008). Metode Penelitian Bisnis. Bandung: Pusat Bahasa Depdiknas

Sugiyono. (2012). Metode Penelitian Kuantitatif Kualitatif dan R\&D. Bandung: Alfabeta

Suwandi., \& Basrowi. (2008). Memahami Penelitian Kualitatif. Jakarta: Rineka Cipta 